\title{
Effect of sawdust as porosity agent on final properties of geopolymers
}

\author{
D. C. Pereira ${ }^{1}$, G. Amaral-Labat ${ }^{1}$, G. F. B. Lenz e Silva ${ }^{1 *}$ \\ ${ }^{1}$ University of São Paulo, Polytechnic School, Department of Materials and Metallurgy Engineering, \\ S. Paulo, SP, Brazil
}

\begin{abstract}
The geopolymers synthesis are based on geopolymerization, a sequence of reactions processed in an alkaline medium through oligomers providing a three-dimensional molecular structure. In this work, the polycondensation of metakaolin was performed with alkaline activators $(\mathrm{NaOH}$ and sodium silicate), wood sawdust and other additives. Two different compositions were evaluated after and before sintering at a high temperature $\left(850^{\circ} \mathrm{C}\right)$. The effect of sawdust addition and the thermal treatment of geopolymers were evaluated by scanning electronic microscopy, X-ray diffraction, mechanical properties, apparent density and porosity by different characterization techniques to guide of development of high porous and low-density materials for thermal and noise control application on building/home construction engineering applications.
\end{abstract}

Keywords: geopolymer, activated metakaolin, refractory material, sawdust.

\section{INTRODUCTION}

Geopolymers are defined as inorganic polymers formed by $\mathrm{SiO}_{4}^{-}$and $\mathrm{AlO}_{4}^{-}$tetrahedrons linked by oxygen bridges and are classified into three different groups according to the atomic ratio between silicon $(\mathrm{Si})$ and aluminum $(\mathrm{Al})$ : i) poly(sialate) (M-PS), ii) poly(sialate siloxo) (M-PSS), and iii) poly(sialate disiloxo) (M-PSDS), where $\mathrm{M}$ stand for a cation as calcium, potassium or sodium [1]. The repeating units of geopolymers are normally based in (-Si$\mathrm{O}-\mathrm{Si}-\mathrm{O}-)$, (-Si-O-Al-), (Fe-O-Si-O-Al-O-) or (-Al-O-P-O-) compounds, which are obtained through polycondensation reactions, from an amorphous compound to a semicrystalline structure [2]. The term geopolymer was used for the first time by Davidovits and initial studies on such materials started around the $1950 \mathrm{~s}$, generating a great interest in Kiev, a scientist from the civil engineering institute in Ukraine, especially because of the excellent performance of those materials when compared to the ordinary Portland cement - OPC [3]. The final compound materials, mainly composed by clay and an alkaline reactant $(\mathrm{KOH}$ or $\mathrm{NaOH}$ ), present good mechanical, thermal and chemical properties generating structures with promising properties for applications like insulators, refractories, and coatings. However, several applications have been explored for those materials as advanced ceramics, toxic waste management, cementitious binders, composites, refractories, fire barrier, cements and concretes [1].

A crucial factor for the production of geopolymers is related to the final molar ratio of components. Several molar ratios have been studied for different authors, as described in Table I, and basically, four relationships should be noticed,

*guilhermelenz@usp.br

(D) https://orcid.org/0000-0003-1184-5271 leading to materials with good mechanical properties. Time and temperature of curing of geopolymers also present a direct impact on the final mechanical properties of the material. Those parameters have been explored in many studies ranging from 20 to $85^{\circ} \mathrm{C}$ and from 1 to 28 days [12, 13] depending on the prepared formulation. In addition, relative humidity has also been controlled in some studies [13]. All parameters as density, porosity and mechanical properties of the geopolymer play an important role for the final application. Hence, a control and evaluation of parameters are required according to the desired application, and then an improvement in acoustic and thermal comfort, for example, in civil construction might also be explored.

Table I - Molar ratios of geopolymer formulations from literature: $\quad \mathrm{Na}_{2} \mathrm{O} / \mathrm{SiO}_{2} ; \quad \mathrm{SiO}_{2} / \mathrm{Na}_{2} \mathrm{O} ; \quad \mathrm{Na}_{2} \mathrm{O} / \mathrm{Al}_{2} \mathrm{O}_{3} ; \quad$ and $\mathrm{SiO}_{2} / \mathrm{Al}_{2} \mathrm{O}_{3}$.

\begin{tabular}{ccccc}
\hline $\mathrm{Na}_{2} \mathrm{O} / \mathrm{SiO}_{2}$ & $\mathrm{SiO}_{2} / \mathrm{Na}_{2} \mathrm{O}$ & $\mathrm{Na}_{2} \mathrm{O} / \mathrm{Al}_{2} \mathrm{O}_{3}$ & $\mathrm{SiO}_{2} / \mathrm{Al}_{2} \mathrm{O}_{3}$ & $\mathrm{Ref}$ \\
\hline- & - & - & $3.40-3.80$ & {$[4]$} \\
- & 1.60 & - & 2.65 & {$[5]$} \\
- & - & - & $3.10-3.30$ & {$[6]$} \\
- & - & 1.00 & 2.33 & {$[7]$} \\
- & - & 1.00 & 5.50 & {$[8]$} \\
- & $0.50-1.00$ & - & $1.15-1.90$ & {$[9,10]$} \\
$0.20-0.48$ & 3.20 & $0.80-1.20$ & $3.30-4.50$ & {$[11]$} \\
0.30 & 1.58 & & 3.80 & \\
& 2.20 & - & 4.70 & {$[12]$} \\
\hline
\end{tabular}

This work showed the development of geopolymers, the evaluation of temperature of sintering and the effect of the addition of sawdust on final properties, always aiming 
high mechanical properties. The final features of materials were mainly regulated by parameters of synthesis as chemical composition and sawdust percentage. Mechanical and morphological properties of all prepared samples were evaluated by compression strength, elastic modulus and SEM images. X-ray diffractions were performed for evaluation of main phases of geopolymers before and after the heat treatment, searching as a goal the development of high porous and low-density material with potential application in thermal and noise control for building and home construction.

\section{MATERIALS AND METHODS}

Geopolymer materials were synthesized based on $\mathrm{Na}_{2} \mathrm{O}-$ $\mathrm{Al}_{2} \mathrm{O}_{3}-\mathrm{SiO}_{2}$ system, in order to attempt specific composition relationship ratios of ternary phase diagram and reach final good mechanical properties after sintering at $850^{\circ} \mathrm{C}$ and with porosity and density control. Table II shows each component that was used with its respective function. Sawdust was composed of several types of wood dried and sieved at $40^{\circ} \mathrm{C}$ and 48 mesh, respectively, presenting particle sizes between $55-350 \mu \mathrm{m}$; the chemical composition of metakaolin was $\mathrm{SiO}_{2} 57 \%, \mathrm{Al}_{2} \mathrm{O}_{3} 34 \%, \mathrm{CaO}+\mathrm{MgO}<0.1 \%, \mathrm{SO}_{3}<0.1 \%, \mathrm{Na}_{2} \mathrm{O}$ $<0.1 \%$, alkaline equilibrium $\mathrm{Na}_{2} \mathrm{O}<1.5 \%, \mathrm{Fe}_{2} \mathrm{O}_{3} 2 \%, \mathrm{TiO}_{2}$ $1.5 \%$ (source: Metacaulim do Brasil).

Two different compositions were defined using linear programming to optimize the chemical composition (Solver routine program of software MS Excel). The compositions and molar ratios of prepared samples are described in Table III and IV, respectively. The formulations $\mathrm{C} 1$ and $\mathrm{C} 2$ are shown on $\mathrm{Na}_{2} \mathrm{O}-\mathrm{SiO}_{2}-\mathrm{Al}_{2} \mathrm{O}_{3}$ ternary phase diagram (Fig. 1). The porosity agent, sawdust, was a low value-added biomass residue from a local sawmill of São Paulo State (Brazil). Samples were prepared with 0 to $20 \mathrm{wt} \%$ of porosity agent in cylindrical form ( $25 \mathrm{~mm}$ in diameter and $80 \mathrm{~mm}$ in height). Curing time ranged from 7 to 10 days at room temperature $\left(\sim 25{ }^{\circ} \mathrm{C}\right)$ and then the samples were dried in an oven at $110{ }^{\circ} \mathrm{C}$. Differential thermal analysis was performed in a TG/DTA equipment (Netzsch, STA 900) under synthetic air atmosphere from 25 to $1400{ }^{\circ} \mathrm{C}$ at $10{ }^{\circ} \mathrm{C} / \mathrm{min}$ using the non-heat-treated samples. After drying, the two compositions were also heated treated at $3.5^{\circ} \mathrm{C} / \mathrm{min}$ in a muffle oven (Jung, LF04213), from room temperature to $850{ }^{\circ} \mathrm{C}$ and the
Table III - Chemical compositions (wt\%) of prepared samples.

\begin{tabular}{cccc}
\hline Composition & $\mathrm{Na}_{2} \mathrm{O}$ & $\mathrm{SiO}_{2}$ & $\mathrm{Al}_{2} \mathrm{O}_{3}$ \\
\hline $\mathrm{C} 1$ & 22.50 & 33.70 & 43.80 \\
$\mathrm{C} 2$ & 21.20 & 51.00 & 28.00 \\
\hline
\end{tabular}

Table IV - Molar ratios of $\mathrm{C} 1$ and $\mathrm{C} 2$ formulations.

\begin{tabular}{ccccc}
\hline \multirow{2}{*}{ Composition } & $\begin{array}{c}\mathrm{Na}_{2} \mathrm{O} / \\
\mathrm{SiO}_{2}\end{array}$ & $\begin{array}{c}\mathrm{SiO}_{2} / \\
\mathrm{Na}_{2} \mathrm{O}\end{array}$ & $\begin{array}{c}\mathrm{Na}_{2} \mathrm{O} / \\
\mathrm{Al}_{2} \mathrm{O}_{3}\end{array}$ & $\begin{array}{c}\mathrm{SiO}_{2} / \\
\mathrm{Al}_{2} \mathrm{O}_{3}\end{array}$ \\
\hline $\mathrm{C} 1$ & 0.64 & 1.56 & 0.85 & 1.31 \\
$\mathrm{C} 2$ & 0.40 & 2.51 & 1.27 & 3.20 \\
\hline
\end{tabular}

set point was maintained for $2 \mathrm{~h}$.

The compression tests for raw dried and thermal treated samples were performed with a Kratos universal hydraulic testing machine according to ASTM NBR7215 standard [14], using a $5000 \mathrm{kgf}$ load cell with a constant load rate of $5.0 \mathrm{~mm} / \mathrm{min}$, where stress and strain were continuously and simultaneously recorded. Cold compressive strength (CCS) was calculated as a function of the transversal area of each sample. Cylindrical specimens were used for determination of Young's modulus, performed with Sonelastic equipment (mod. SA-BC) using the software Sonelastic v. 3.0. This technique, a non-destructive method, is based on the impulse excitation of the sample for the determination of elastic modulus through the natural vibration frequencies of the material. The apparent density (AD) was measured by Archimedes method, using water as a liquid in a Shimadzu semi-analytical balance - AY220 [15], and the apparent porosity (AP) was calculated from such density. The tests were performed with at least four samples. Surface morphology and porosity of geopolymers, previously metalized with gold, were investigated by scanning electron microscopy (SEM, FEI, Inspec F50). The chemical elements on the surface of geopolymers were analyzed by energy dispersive X-ray spectroscopy (EDS) using EDAX and TEAM software. The phase compositions before and after thermal treatment were evaluated by $\mathrm{X}$-ray diffraction (XRD) in a Bruker diffractometer with $\mathrm{CuK} \alpha$ radiation, $\lambda=1.54178 \AA$, and a scan rate of $0.02 \%$.

Table II - Raw materials and chemicals used.

\begin{tabular}{llll}
\hline Material & Supplier & Type & Function \\
\hline Metakaolin & Metacaulim do Brasil & Binder & $\begin{array}{l}\text { Provide structure and formation of } \\
\text { geopolymer/alumina sodium silicate }\end{array}$ \\
Sawdust & Local supplier & Porosity agent & Adjust porosity \\
Sodium hydroxide (p.a.) & Neon & Activator & Activator, source of $\mathrm{Na}^{+}$ \\
Sodium silicate (p.a.) & Diatom Co. & Activator & Activator, source of $\mathrm{Na}^{+}$ \\
Microsilica (960) & Elkem & Component & Source of $\mathrm{SiO}_{2}$ \\
Calcined alumina (A1000 SG) & Almatis & Component & Source of $\mathrm{Al}_{2} \mathrm{O}_{3}$ \\
\hline
\end{tabular}




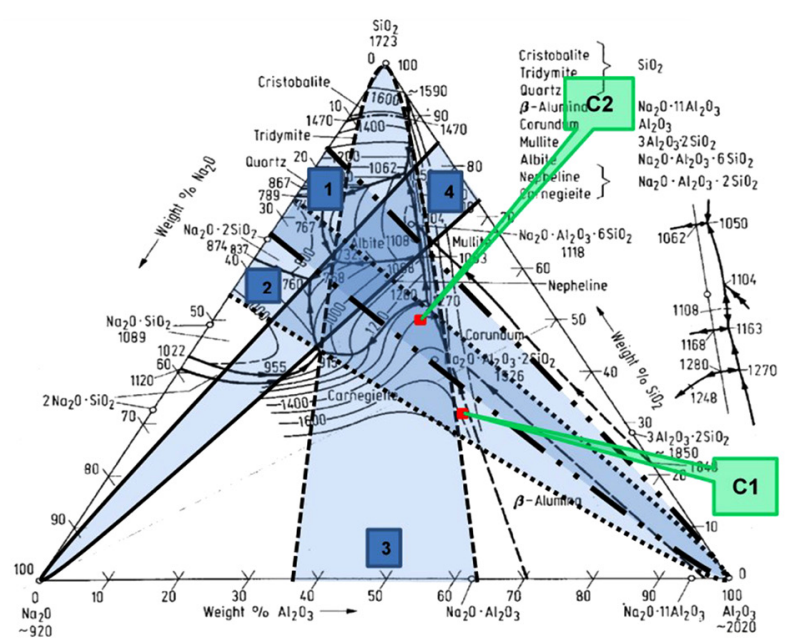

Figure 1: $\mathrm{SiO}_{2}-\mathrm{Al}_{2} \mathrm{O}_{3}-\mathrm{Na}_{2} \mathrm{O}$ phase diagram with geopolymers molar ratios (regions 1-4); adapted from [16]

\section{RESULTS AND DISCUSSION}

The thermal behavior of two studied compositions in presence of air was evaluated from DTA analysis (synthetic air, $10^{\circ} \mathrm{C} / \mathrm{min}$ of heating rate, Fig. 2). Thermal analysis of $\mathrm{C} 1$ and $\mathrm{C} 2$ compositions showed important phase transformations at temperatures up to $800{ }^{\circ} \mathrm{C}$. The main contributions from $250-600{ }^{\circ} \mathrm{C}$ were related to evaporation of free water and condensation of aluminol and silanol groups [7]. The main crystalline phases of $\mathrm{C} 1$ and $\mathrm{C} 2$ before and after treatment are presented on Fig. 3 . The XRD patterns showed the presence of hydrosodalite and low quartz for both compositions before calcination. However, after the thermal treatment, C1HT was basically composed of nepheline and cristobalite while the main phases found for $\mathrm{C} 2 \mathrm{HT}$ were nepheline, cristobalite, and low quartz.

Fig. 4 shows the effect of both the sawdust percentages and the thermal treatment on apparent density of all samples. A reduction of apparent density was observed for samples without heat treatment, probably due to the lower specific gravity of sawdust compared to metakaolin,

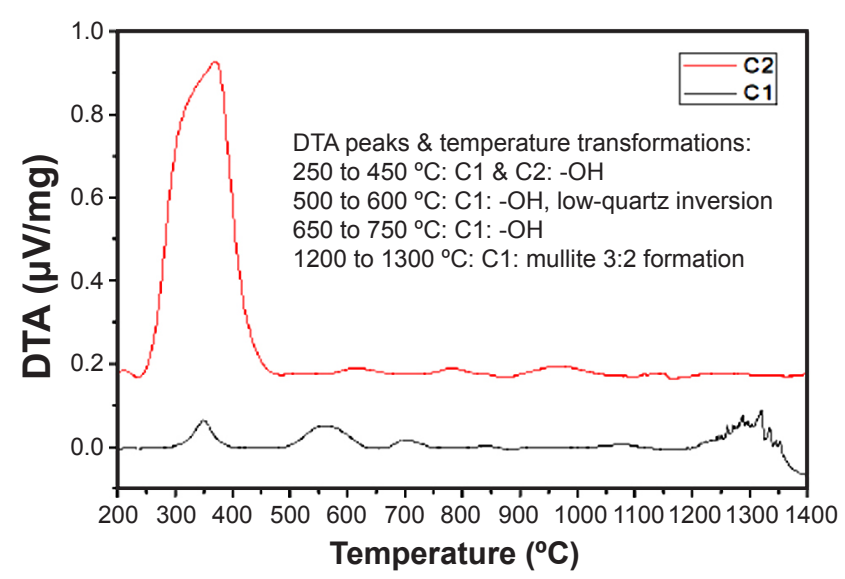

Figure 2: Differential thermal analysis behavior of compositions $\mathrm{C} 1$ and $\mathrm{C} 2$.

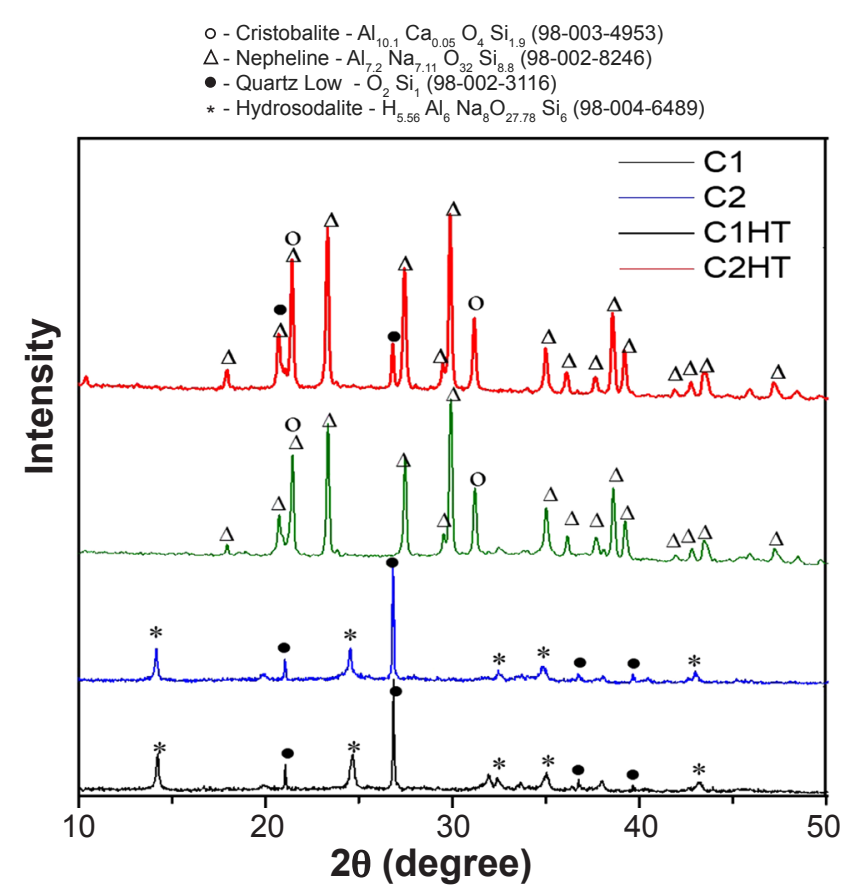

Figure 3: XRD patterns of geopolymers before $(\mathrm{C} 1, \mathrm{C} 2)$ and after (C1HT, C2HT) calcination.

in agreement with geopolymers prepared with a different biomass source (rice husk) [17]. The apparent density always increased after sintering at $850{ }^{\circ} \mathrm{C}$ and tended to increase with the sawdust addition. Apparent porosity was higher for $\mathrm{C} 2$ compositions compared to $\mathrm{C} 1$, regarding the samples without heating, showing that compositions presented different behavior (Fig. 5a). However, after thermal treatment, porosity increased in a higher proportion for $\mathrm{C} 1$, values ranging from $34 \%$ to $47 \%$, in contrast to $25 \%$ to $34 \%$ of C2 . Besides, the C2HT-20\% sawdust showed no increase in porosity, remaining at $34 \%$. Those differences on porosity were also due to the volume shrinkage, clearly seen in Fig. 6. The composition 2 presented higher shrinkage values leading to more compact materials, especially the C2HT-20\% sawdust,

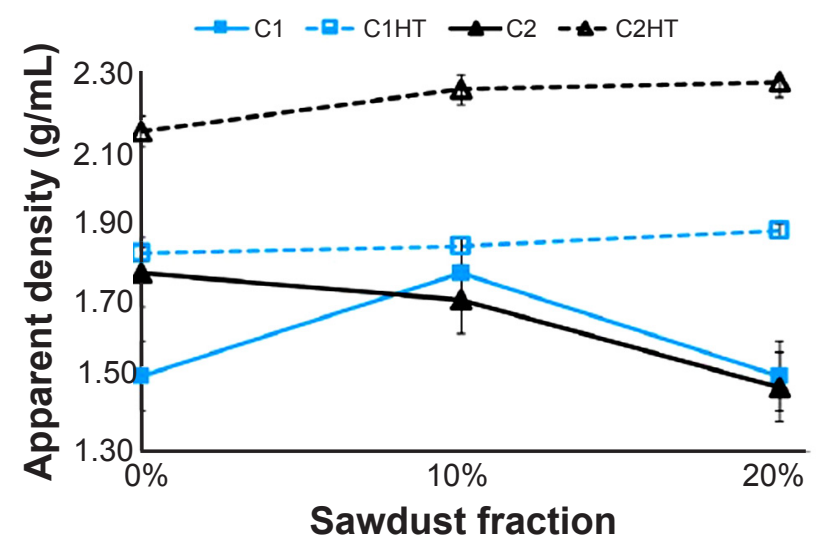

Figure 4: Apparent density for the samples with different percentages of sawdust before and after thermal treatment (HT), full and empty symbols, respectively. 


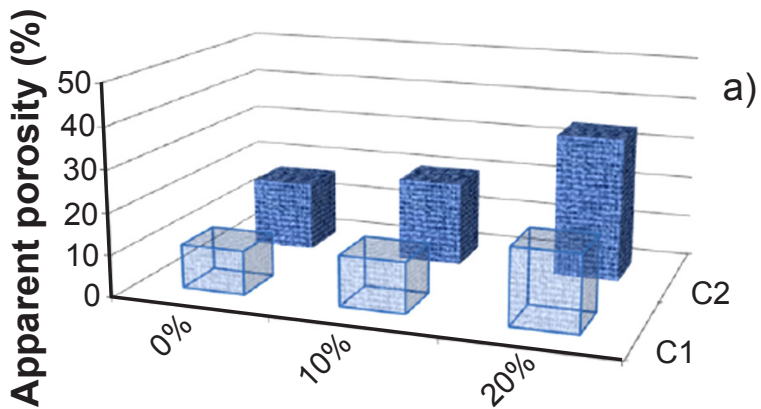

Sawdust fraction

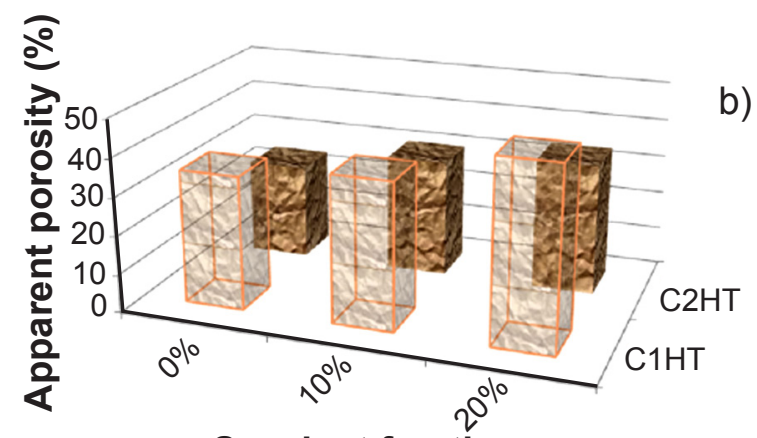

Sawdust fraction

Figure 5: Apparent porosity (AP) for samples before (a) and after (b) heat treatment with different percentages of sawdust.

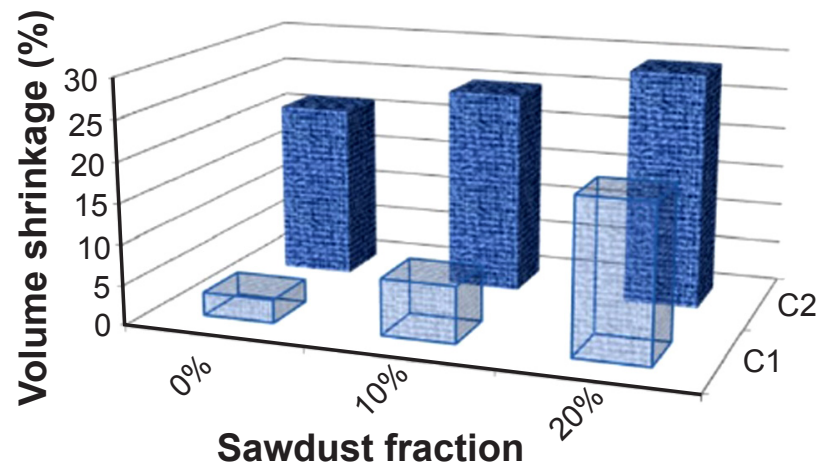

Figure 6: Volume shrinkage for samples after treatment at $850^{\circ} \mathrm{C}$.

corroborating the absence of increment of porosity for such composition after the calcination.

Morphology and porosity were evaluated by SEM at different magnifications. Micrographs clearly showed the increase in porosity with the addition of sawdust (Fig. 7b) compared to the morphology of the geopolymeric matrix (Fig. 7a). A large distribution of pores, with different sizes, was found on the matrix probably due to the air entrapment during the mixing, assisted by the presence of sawdust particles on the composition (Fig. 7c); such pores were mostly isolated (closed porosity). Furthermore, porosity also increased with the thermal treatment at 850 ${ }^{\circ} \mathrm{C}$ resulting in a rough surface and a highly porous matrix (Figs. 7d and 7e). Such final structure might represent an important characteristic for applications as thermal insulators or sound absorbing materials [18]. The sawdust fiber found on the geopolymer structure, as shown in Fig. 7c, was confirmed by EDS analysis, which showed a remarkable peak of carbon normally found for biomass materials (pore forming agent) in a raw form.
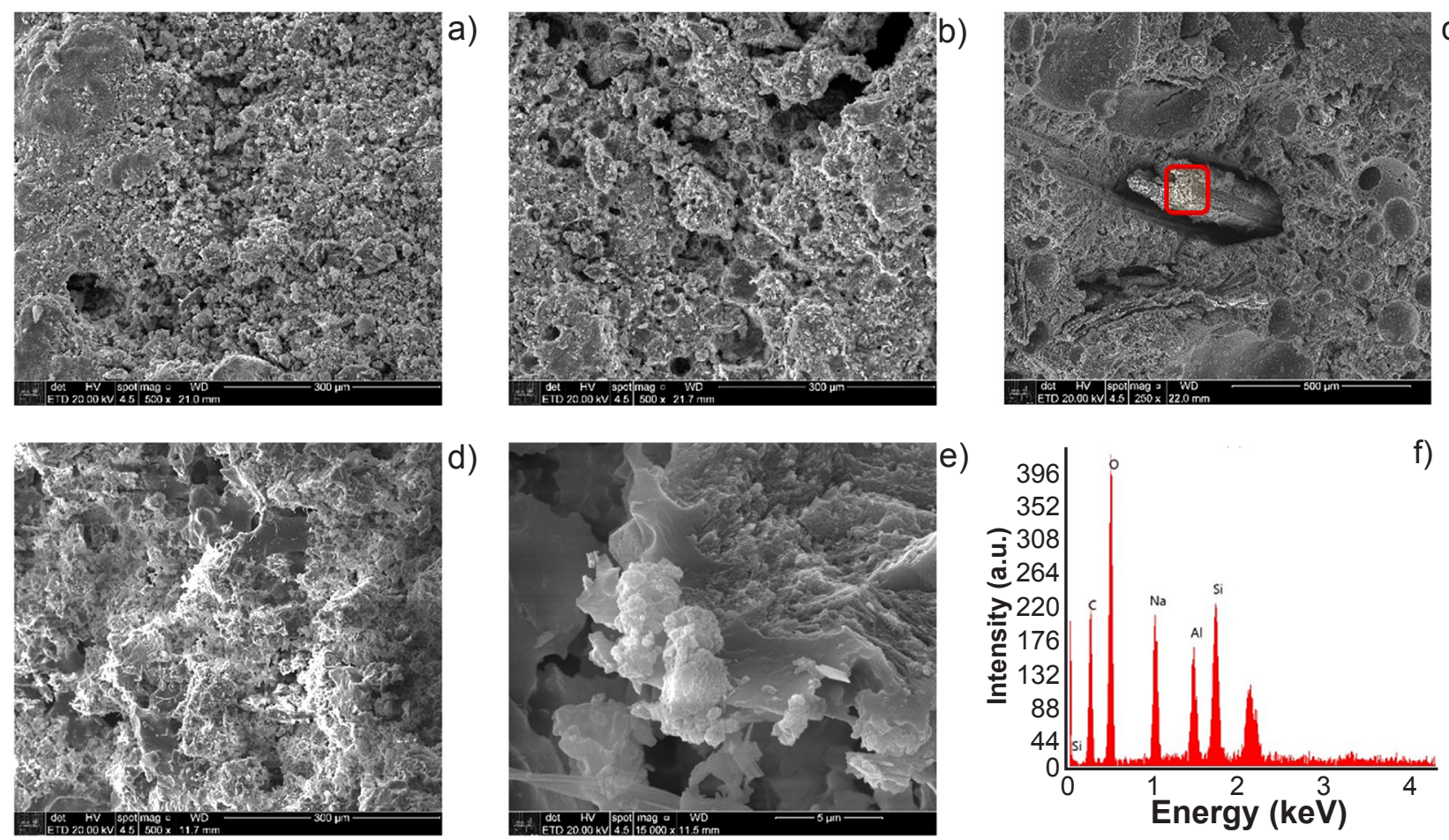

Figure 7: SEM micrographs of the samples (fraction of sawdust): a) C1 (0\%); b) C1 (10\%); c) C2 (20\%); d,e) C1HT (0\%) at different magnifications; and EDS spectrum (f) of the region indicated with a red square in (c). 

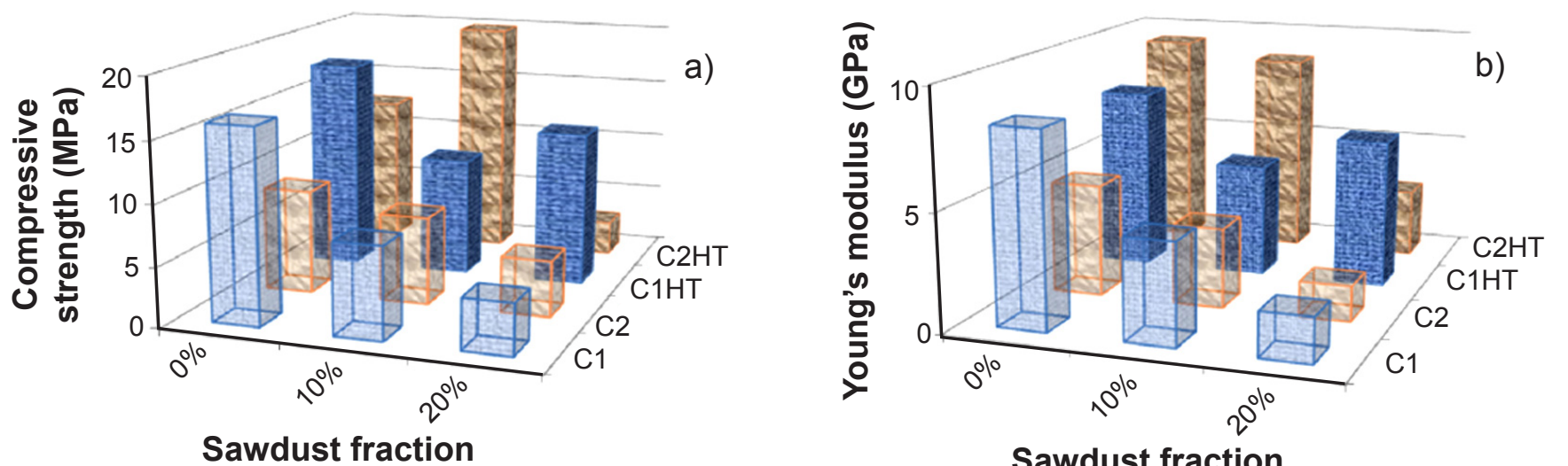

Figure 8: Cold compressive strength, CCS (a), and Young's modulus, E (b), for all samples before and after thermal treatment with different percentages of sawdust.

The mechanical properties of metakaolin-based geopolymers were evaluated before and after the sintering process. Before the heat treatment, the values ranged from 4.21 to $16.04 \mathrm{MPa}$ (Fig. 8a) in agreement to a large variety of values found in the literature $(0-$ $132 \mathrm{MPa})[6,13,17,19,20]$. However, it is important to point out that the final properties of geopolymers as compressive strength have a direct relationship with the synthesis conditions, calcination temperature of metakaolin, properties, proportions, and kinds of raw material, among others [20]. The increase in temperature of the geopolymers usually causes loss of compressive strength attributed to evaporation of free, chemically and physically bonded water in the geopolymeric structure. This 'vapor effect' is defined by the water pressure in the geopolymer reaching the maximum limit, causing shrinkage and cracks in the geopolymer matrix $[13,19]$. However, in this study only C2HT composition (20\% sawdust) showed loss of compressive strength (40\%). All other formulations showed significant increases: $10 \%$ to $67 \%$ for $\mathrm{C} 1$ formulations, while composition 2 showed an increase of $45 \%$ and $172 \%$ for C2HT $(0 \%)$ and C2HT-10\% sawdust, respectively. Probably, the expected reduction of mechanical properties associated to the vapor generation effect and to the wood (sawdust) thermal decomposition was by far compensated by both the sintering process and the high shrinkage of materials. Another factor that worked to decrease the mechanical compressive strength of C2HT compared with C1HT came from the volumetric transformation of low quartz inversion around $573{ }^{\circ} \mathrm{C}$. These results are relevant when compared with values of geopolymers from metakaolin or fly ash sintered between 300 and $1000{ }^{\circ} \mathrm{C}$, because in these cases there was always a significant loss of mechanical properties $[13,19]$. The Young's modulus of geopolymers followed the general trend of compressive strength (Fig. 8b). Further modifications were observed in C2HT because for this formulation the heat treatment caused a significant increase in such parameter, especially for $0 \%$ and $10 \%$ of sawdust. In general, the values found in this work were slightly higher (1.5 to $9.4 \mathrm{GPa})$ than those found in the literature (0.9-7.0 GPa) [9, 10], also confirming the high rigidity of the synthesized materials.

\section{CONCLUSIONS}

In the system $\mathrm{Na}_{2} \mathrm{O}-\mathrm{Al}_{2} \mathrm{O}_{3}-\mathrm{SiO}_{2}$, different compositions were obtained, in order to attempt the Davidovits molar ratios and special ternary phase compositions, aiming to produce geopolymers with low sintering temperature. The sawdust addition, the chemical composition, and the thermal treatment produced a direct impact on final properties of geopolymers. As expected, the increase of apparent porosity decreased the cold compressive strength values. However, the prepared compositions of $\mathrm{Na}_{2} \mathrm{O}-\mathrm{Al}_{2} \mathrm{O}_{3}-\mathrm{SiO}_{2}$ presented high mechanical properties even after calcination with higher proportions of the porous agent, showing that several applications might be explored with these samples, such as the production of special geopolymer panels to control heat transferring and noise in building construction walls and slabs.

\section{ACKNOWLEDGMENTS}

This study was financed in part by the Coordenação de Aperfeiçoamento de Pessoal de Nível Superior - Brasil (CAPES) - Finance Code 001. Authors would like to thank Capes, CNPq, Almatis Ltd., Metacaulim do Brasil and Diatom.

\section{REFERENCES}

[1] J. Davidovits, Geopolymer chemistry and applications, $2^{\text {nd }}$ ed., Inst. Géopolym. (2008).

[2] C.S. Bitencourt, B.H. Teider, J.B. Gallo, V.C. Pandolfelli, Cerâmica 58, 345 (2012) 20.

[3] P.H.R. Borges, T.M.F. Lourenço, A.F.S. Toureaux, L.S. Pacheco, Amb. Constr. 14, 2 (2014) 153.

[4] C.G.S. Severo, D.L. Costa,I.M.T. Bezerra, R.R. Menezes, G.A. Neves, Rev. Eletron. Mat. Proc. 8, 2 (2013) 55. 
[5] R.A.A.B. Santa, J. Nones, H.G. Riella, N.C. Kuhenen, in: Blucher Chem. Eng. Proc. 1-2 (2015) 9290.

[6] P.H.R. Borges, N. Banthia, H.A. Alcamand, W.L. Vasconcelos, E.H.M. Nunes, Cem. Concr. Compos. 71 (2016) 42.

[7] N. Saidi, B. Samet, S. Baklout, Int. J. Mater. Sci. 3, 4 (2013) 145 .

[8] F.G.M. Aredes, T.M.B. Campos, J.P.B. Machado, K.K. Sakane, G.P. Thim, D.D. Brunelli, Ceram. Int. 41, 6 (2015) 7302.

[9] P. Duxson, J.L. Provis, G.C. Lukey, S.W. Mallicoat, W.M. Kriven, J.S.J. Van Deventer, Colloids Surf. A 269, 1-3 (2005) 47.

[10] P. Duxson, S.W. Mallicoat, G.C. Lukey, W.M. Kriven, J.S.J. Van Deventer, Colloids Surf. A 292, 1 (2007) 8.

[11] U. Rattanasak, P. Chindaprasirt, Miner. Eng. 22, 12 (2009) 1073.

[12] R.H. Geraldo, G. Camarini, Int. J. Eng. Technol. 7, 5 (2015) 390 .
[13] G. Wenying, W. Guolin, W. Jianda, W.Ziyun, Y. Suhong, J. Wuhan Univ. Technol. Mater. Sci. Ed. 23, 3 (2008) 326.

[14] ABNT, NBR7215, "Portland cement - determination of compressive strength" (1996).

[15] ABNT, NBR 16661, "Dense shaped refractory materials - determination of apparent volume, apparent volume of the solid part, bulk density, apparent density of the solid part, apparent porosity and absorption" (2017).

[16] V.D. Eisenhuttenleute, Slag atlas, $2^{\text {nd }}$ ed., Verlag Stahleisen, Düsseldorf (1995).

[17] P.H.R. Borges, V.A. Nunes, T.H. Panzera, G. Schileo, A. Feteira, Open Construc. Build. Tecnnol. J. 10 (2016) 406. [18] C. Bai, G. Franchin, H. Elsayed, A. Zaggia, L. Conte, H. Li, P. Colombo, J. Mater. Res. 32, 17 (2017) 3251.

[19] O.A. Abdulkareem, A.M.M. Al Bakri, H. Kamarudin, I.K. Nizar, A.A. Saif, Constr. Build. Mater. 50 (2014) 377.

[20] Z.H. Zhang, H.J. Zhu, C.H. Zhou, H. Wang, Appl. Clay Sci. 119 (2016) 31.

(Rec. 29/09/2018, Rev. 13/11/2018, 29/11/2018, Ac. $07 / 12 / 2018)$ 